\title{
ANALISIS FAKTOR-FAKTOR YANG MEMPENGARUHI PENYERAPAN ANGGARAN PENDAPATAN DAN BELANJA DAERAH (APBD) PEMERINTAH KABUPATEN KEPULAUAN TALAUD
}

\author{
LEDY S. GAGOLA ${ }^{1)}$ JULLIE J. SONDAKH ${ }^{2)}$ JESSY D.L. WARONGAN ${ }^{3)}$ \\ Program Studi Magister Akuntansi Fakultas Ekonomi dan bisnis Universitas Sam Ratulangi \\ E-mail : jcluvega14@gmail.com
}

\begin{abstract}
Budget is a statement regarding the estimation of the performance to be achieved during a certain period of time stated in the financial measures and expressed how much it costs to the plans made (expenses / expenditures) as well as how much and how to get money to fund the plan. Budget (APBD) is the annual local government financial policy which is based on statutory provisions in force, a number of considerations for the formulation, monitoring, control and evaluation is done. Absorption of budget revenues and expenditures significantly influence the increasing of regional economic growth. The average absorption of budget revenues and expenditures Government Talaud Islands in the year 2012-2015 was 94.03\%. This study is aimed to analyze the factors that influence the absorption of budget revenues and expenditures (budget) on the Talaud Islands Government. The data used in this research were primary data. Data were collected by using questionnaires. This is a quantitative research with multiple linear regression analysis. There are five independent variables and one dependent variable. Those five independent variables are planning budget (X1), the implementation of the budget $(X 2)$, the procurement of goods and services (X3), management commitment (X4), and bureaucracy (X5). The dependent variable is the budget absorption (Y). The results show that either simultaneously or partially, budget planning, budget execution, procurement of goods and services, management commitment and bureaucratic environment positively and significantly influence the absorption of budget revenues and expenditures (budget) in the Talaud Islands Government. The magnitude of the effect of these five variables against excess absorption can be described by the coefficient of determination at $73.3 \%$ and the remaining of $26.7 \%$ is influenced by other factors excluded within this research.
\end{abstract}

Keywords: Budget Planning, Budget Implementation, Procurement of Goods and Services, Commitment of Management, and Environment of Bureaucracy

Abstrak. Anggaran merupakan pernyataan mengenai estimasi kinerja yang hendak dicapai selama periode waktu tertentu yang dinyatakan dalam ukuran finansial dan menyatakan berapa biaya atas rencana-rencana yang dibuat (pengeluaran/belanja) serta berapa banyak dan bagaimana caranya memperoleh uang untuk mendanai rencana tersebut. Anggaran Pendapatan dan Belanja Daerah (APBD) adalah kebijakan keuangan tahunan pemerintah daerah yang disusun berdasarkan ketentuan perundang-undangan yang berlaku, dengan berbagai pertimbangan agar penyusunan, pemantauan, pengendalian dan evaluasi mudah dilakukan. Penyerapan anggaran pendapatan dan belanja daerah memiliki pengaruh yang cukup signifikan dalam mendorong pertumbuhan ekonomi daerah. Rata-rata penyerapan anggaran pendapatan dan belanja daerah Pemerintah Kabupaten Kepulauan Talaud pada tahun 2012-2015 sebesar 94,03\%. Penelitian ini bertujuan untuk menganalisis faktor-faktor yang mempengaruhi penyerapan anggaran pendapatan dan belanja daerah (APBD) pada Pemerintah Kabupaten Kepulauan Talaud. Sumber data yang digunakan dalam penelitian ini adalah data primer dan pengumpulan data dilakukan secara langsung dengan menggunakan kuesioner. Metode penelitian yang digunakan adalah metode kuantitatif dengan analisis regresi linear berganda. Pada penelitian ini digunakan lima variabel independen dan satu variabel dependen, lima variabel independen tersebut adalah perencanaan anggaran (X1), pelaksanaan anggaran (X2), pengadaan barang jasa (X3), komitmen manajemen (X4), lingkungan birokrasi (X5), sedangkan satu variabel dependen adalah penyerapan anggaran (Y). Hasil penelitian menunjukkan bahwa baik secara simultan maupun parsial perencanaan anggaran, pelaksanaan anggaran, pengadaan barang jasa, komitmen manajemen dan lingkungan birokrasi berpengaruh positif dan signifikan terhadap penyerapan anggaran pendapatan dan belanja daerah (APBD) Pemerintah Kabupaten Kepulauan Talaud. Besarnya pengaruh kelima variabel tersebut terhadap penyerapan anggaran yang dapat dijelaskan oleh nilai koefisien determinasi adalah sebesar $73,3 \%$ sedangkan sisanya $26,7 \%$ dipengaruhi oleh faktor lain diluar penelitian.

Kata Kunci: Perencanaan Anggaran, Pelaksanaan Anggaran, Pengadaan Barang Jasa, Komitmen Manajemen, Lingkungan Birokrasi 


\section{Pendahuluan}

Desentralisasi merupakan penyerahan urusan pemerintahan oleh pemerintah pusat kepada daerah otonom sebagaimana yang diatur dalam Undang-Undang Nomor 9 Tahun 2015 tentang Pemerintahan Daerah. Asas otonomi memberikan keleluasaan kepada kepala daerah baik di provinsi, kabupaten maupun kota untuk mengelola sumber daya yang dimiliki supaya tujuan pemerintahan dapat tercapai.Penjelasan umum Undang-Undang Nomor 9 Tahun 2015 tentang Pemerintah Daerah menyebutkan pemberian otonomi kepada daerah diarahkan untuk mempercepat terwujudnya kesejahteraan masyarakat melalui peningkatan pelayanan, pemberdayaan, dan peran serta masyarakat. Pemerintah daerah diharapkan dapat mencapai tujuannya melalui penyerapan anggaran yang maksimal karena setiap daerah dapat memanfaatkan segala potensi sumber daya yang dimilikinya.

Undang-undang Nomor 17 Tahun 2003 tentang Keuangan Negara, menyatakan bahwa anggaran adalah alat akuntabilitas, manajemen dan kebijakan ekonomi. Anggaran sebagai kebijakan ekonomi yang berfungsi untuk mewujudkan pertumbuhan dan stabilitas perekonomian serta pemerataan pendapatan dalam rangka mencapai tujuan Negara.

Menurut Bastian (2006), Anggaran Pendapatan dan Belanja Daaerah (APBD) adalah merupakan pengejawantahan rencana kerja Pemerintah Daerah dalam bentuk satuan uang untuk kurun waktu satu tahunan dan berorientasi pada tujuan kesejahteraan publik.

Peraturan Menteri Keuangan Nomor 249/PMK.02/2011 menyebutkan bahwa penyerapan anggaran merupakan salah satu indikator evaluasi kinerja atas aspek implementasi. Penyerapan anggaran juga merupakan salah satu unsur akuntabilitas keuangan pada Laporan Akuntabilitas Kinerja Instansi Pemerintah (LAKIP).

Di Indonesia, lambatnya penyerapan anggaran menjadi masalah klasik yang terus terjadi setiap tahunnya. Hal ini berdampak pada lambatnya realisasi pelaksanaan program dan kegiatan pemerintah. Fenomena ini juga terjadi pada Pemerintah Kabupaten Kepulauan Talaud. sebagai gambaran selama periode tahun anggaran 2012-2015, di laporan realisasi anggaran pemerintah daerah mencatat hampir setiap tahun anggaran ada dana yang tidak terealisasi di kas daerah.

Kegagalan target penyerapan anggaran berakibat hilangnya manfaat belanja, karena dana yang dialokasikan ternyata tidak semua dapat dimanfaatkan oleh pemerintah yang artinya ada dana yang menganggur (BPKP,2011). Berdasarkan teori dan penelitian terdahulu, faktor-faktor yang mempengaruhi penyerapan anggaran antara lain perencanaan anggaran, pelaksanaan anggaran, pengadaan barang jasa, komitmen manajemen dan lingkungan birokrasi.

Perencanaan merupakan unsur penting di dalam organisasi. Perencanaan menentukan semua aktivitas yang perlu dan akan dilakukan untuk mencapai tujuan dan sasaran yang ingin dicapai. Untuk merealisasikan perencanaan dibutuhkan anggaran. Anggaran merupakan cetak biru untuk gambaran, tindakan dan formalitas dari proses perencanaan (Darmanegara, 2010). Sebagaimana hasil laporan Direktorat Jenderal Perimbangan Keuangan (2013) bahwa besar kecilnya tingkat penyerapan belanja daerah dalam mendanai pelayanan publik sangat dipengaruhi oleh proses perencanaan anggaran. Penelitian Sukadi (2012), membuktikan bahwa perencanaan anggaran berpengaruh positif dan signifikan terhadap penyerapan anggaran.

Pelaksanaan anggaran merupakan tahapan pengelolaan keuangan yang harus dilaksanakan setelah proses perencanan anggaran selesai. Pelaksanaan merupakan aktivitas usaha-usaha yang dilaksanakan untuk merealisasikan semua rencana dan kebijakan yang telah dirumuskan dan ditetapkan (BPKP, 2011). Proses pelaksanaan anggaran meliputi persoalanpersoalan dalam internal satuan kerja, serta proses mekanisme pembayaran (pencairan anggaran). Kedua hal tersebut mempengaruhi besar kecilnya penyerapan anggaran. Penelitian 
Kuswoyo (2011) membuktikan bahwa pelaksanaan anggaran berpengaruh terhadap penyerapan anggaran.

Untuk mempercepat penyerapan anggaran, pemerintah mengatur tata cara pengadaan barang jasa dengan mengeluarkan Peraturan Presiden Nomor 70 Tahun 2012 tentang perubahan kedua Peraturan Presiden Nomor 54 Tahun 2010 tentang pengadaan barang dan jasa. Dalam Peraturan Presiden tersebut dijelaskan pengadaan barang jasa adalah kegiatan untuk memperoleh barang jasa oleh Kementerian/ Lembaga/ Satuan Kerja Perangkat Daerah / Institusi yang prosesnya dimulai dari perencanaan kebutuhan sampai diselesaikannya seluruh kegiatan untuk memperoleh barang jasa. Penelitian Sukadi (2012), membuktikan bahwa pengadaan barang jasa berpengaruh positif dan signifikan terhadap penyerapan anggaran.

Anggaran di sektor publik berisi komitmen atau kesanggupan manajemen untuk mencapai sasaran yang ditetapkan (Halim dan Kusufi, 2012). Komitmen manajemen didefinisikan sebagai kegiatan melakukan dan mempertahankan perilaku yang membantu bawahan untuk mencapai suatu tujuan (Cooper, 2006). Komitmen manajemen yang tinggi dapat menjadi dasar untuk intervensi (Rodgers et al. 1993) sehingga organisasi dapat mencapai penyerapan anggaran secara maksimal. Komitmen manajemen dapat mempengaruhi kinerja organisasi (Babakus et al. 2003). Penelitian Juliani (2014) membuktikan bahwa komitmen manajemen berpengaruh positif terhadap penyerapan anggaran.

Eisenstadt (1959) menyatakan bahwa birokrasi dapat dipandang sebagai sebuah lambang rasionalitas dan implementasi yang efisien dari tujuan dan penyediaan layanan. Lingkungan birokrasi yang baik akan membuat pelaksanaan kegiatan operasional menjadi lancar. Namun jika lingkungan birokrasi tidak mendukung kegiatan organisasi maka akan menghambat kinerja organisasi (Eisenstadt, 1959). Oleh karena itu, lingkungan birokrasi akan mempengaruhi penyerapan anggaran. Penelitian Juliani (2014) membuktikan bahwa lingkungan birokrasi berpengaruh positif terhadap penyerapan anggaran.

\section{Metode Penelitian}

Penelitian ini merupakan jenis penelitian kuantitatif yang bertujuan menganalisis dan mendapatkan bukti empiris pengaruh perencanaan anggaran (X1), pelaksanaan anggaran (X2), pengadaan barang jasa (X3), komitmen manajemen (X4), lingkungan birokrasi (X5) sebagai variabel independen terhadap penyerapan anggaran $(Y)$ sebagai variabel dependen. Teknik analisis yang digunakan adalah analisis regresi linear berganda.

Penelitian ini dilakukan pada Pemerintah Kabupaten Kepulauan Talaud Provinsi Sulawesi Utara. Dengan jumlah responden sebanyak 100 orang (4 orang per SKPD) tersebar di 25 SKPD yang terdiri dari 1 orang Pejabat Penatausahaan Keuangan (PPK) SKPD, 1 orang Pejabat Pembuat Komitmen (PPKom), 1 orang Pejabat Pelaksana Teknis Kegiatan (PPTK), 1 orang Bendahara Pengeluaran. Sumber data yang digunakan adalah data primer melalui pembagian kuesioner. Setelah kuesioner terkumpul maka dilakukan uji validitas dan uji reliabilitas.

Perencanaan anggaran diukur dengan indikator penyusunan RKA, penetapan rancangan APBD, penetapan APBD, dengan menggunakan 7 (tujuh) pernyataan. Pelaksanaan anggaran diukur dengan indikator penunjukan SK pejabat perbendaharaan, budaya kerja, proses penyelesaian administrasi, jadwal anggaran kas, proses verifikasi SPM, dengan menggunakan 8 (delapan) pernyataan. Pengadaan barang jasa diukur dengan indikator jumlah pejabat/panitia pengadaan barang jasa, pemahaman peraturan, pembentukan struktur organisasi pengadaan barang jasa, penentuan harga perkiraan sendiri (HPS), pemilihan penyedia barang jasa, dengan menggunakan 8 (delapan) pernyataan. Komitmen manajemen diukur dengan indikator mencapai target penyerapan, mendukung pelatihan terkait (perencanaan, pengelolaan keuangan, pengadaan barang jasa), memberikan solusi atas persoalan yang terjadi disatuan kerja, dengan menggunakan 6 (enam) pernyataan. Lingkungan birokrasi diukur dengan 
indikator koordinasi antar pegawai terjalin dengan baik, jumlah pegawai yang terlibat terkait pengelolaan keuangan dan pengadaan barang jasa mencukupi, pemahaman peraturan, dengan menggunakan 7 (tujuh) pernyataan. Masing-masing item pernyataan tersebut kemudian diukur dengan menggunakan Skala Likert 5 point.

\section{Hasil dan Pembahasan}

Pengujian validitas dalam penelitian ini menggunakan Pearson Correlation yaitu dengan cara menghitung korelasi antara skor masing-masing butir pernyataan dengan skor total. Jika korelasi antara skor masing-masing butir pernyataan dengan skor total mempunyai tingkat signifikansi $<0,05$, maka butir pernyataan tersebut dinyatakan valid dan sebaliknya (Sugiyono, 2012). Semua item pernyataan untuk variabel perencanaan anggaran, pelaksanaan anggaran, pengadaan barang jasa, komitmen manajemen dan lingkungan birokrasi dinyatakan valid dengan nilai signifikansi $<0,05$. Hal ini berarti semua item pernyataan yang digunakan dalam penelitian ini mampu mengungkapkan semua variabel yang diukur pada kuesioner tersebut.

Uji reliabilitas dilakukan menggunakan teknik Cronbach Alpha. Jika nilai koefisien alpha > 0,60 maka disimpulkan bahwa instrumen penelitian tersebut handal atau reliable (Ghozali, 2005). Berdasarkan uji reliabilitas menunjukkan nilai Cronbach's Alpha untuk variabel perencanaan anggaran sebesar 0,898; pelaksanaan anggaran sebesar 0,688 ; pengadaan barang jasa sebesar 0,837; komitmen manajemen sebesar 0,883; lingkungan birokrasi sebesar 0,827 dan penyerapan anggaran sebesar 0,801 . Dengan demikian pengukuran kuesioner ini reliable karena memiliki nilai Cronbach's Alpha $>0,60$.

Uji normalitas dilakukan untuk mengetahui data berdistribusi normal. Uji normalitas dalam penelitian ini dengan menggunakan grafik P-Plot SPSS dan uji normalitas Kolmogorov-Smirnov. Untuk uji pola penyebaran P-Plot, jika titik-titik data menyebar disekitar garis diagonal dan penyebaran titik-titik data searah mengikuti garis diagonal maka dapat dikatakan data berdistribusi normal. Sedangkan pada uji normalitas Kolmogorov-Smirnov akan dilihat nilai signifikansinya apabila lebih dari 0,05 maka data tersebut berdistribusi normal (Ghozali, 2005). Berdasarkan uji normalitas dengan grafik P-Plot SPSS, didapatkan bahwa titik data menyebar di sekitar garis diagonal dan penyebaran titik-titik data searah mengikuti garis diagonal. Berdasarkan uji normalitas Kolmogorov-Smirnov dilihat bahwa nilai asymp.sig (2-tailed) atau signifikansi sebesar 0,722 lebih besar dari 0.05 sehingga dapat disimpulkan bahwa data yang diuji berdistribusi normal. Dengan demikian model regresi telah memenuhi asumsi normalitas.

Uji multikolinieritas dilakukan untuk melihat apakah pada model regresi ditemukan adanya korelasi antara variabel independen. Cara mendeteksinya adalah dengan melihat nilai tolerance dan nilai Variance Inflation Factor (VIF). Jika nilai VIF $<10$ dan tolerance $>0,1$ maka variabel independen terbebas dari persoalan multikolinieritas (Priyatno, 2013). Hasil uji SPSS menunjukkan bahwa semua nilai tolerance $>0,1$ dan nilai $\mathrm{VIF}<10$.

Tabel 1. Hasil Regresi Linear Berganda

\begin{tabular}{|c|c|c|c|c|c|c|c|c|}
\hline \multicolumn{7}{|c|}{ Coefficients $^{\mathrm{a}}$} & \multirow{2}{*}{\multicolumn{2}{|c|}{ Collinearity Statistics }} \\
\hline & \multirow[t]{2}{*}{ Model } & \multicolumn{2}{|c|}{$\begin{array}{l}\text { Unstandardized } \\
\text { Coefficients }\end{array}$} & \multirow{2}{*}{$\begin{array}{c}\begin{array}{c}\text { Standardized } \\
\text { Coefficients }\end{array} \\
\text { Beta }\end{array}$} & \multirow[t]{2}{*}{$\mathrm{T}$} & \multirow[t]{2}{*}{ Sig. } & & \\
\hline & & $B$ & Std. Error & & & & Tolerance & VIP \\
\hline \multirow{6}{*}{1} & (Constant) & 2.247 & 1.414 & & 1.589 & .155 & & \\
\hline & Perencanaan anggaran & .140 & .060 & .214 & 2.338 & .021 & .323 & 2.095 \\
\hline & Pelaksanaan anggaran & .148 & .065 & .185 & 2.288 & .024 & .411 & 2.435 \\
\hline & Pengadaan barang jasa & .087 & .043 & .172 & 2.048 & .043 & .382 & 2.619 \\
\hline & Komitmen manajemen & .206 & .058 & .299 & 3.538 & .001 & .377 & 2.653 \\
\hline & Lingkungan birokrasi & .102 & .042 & .154 & 2.454 & .016 & .685 & 1.460 \\
\hline
\end{tabular}

Hal ini menunjukkan bahwa semua variabel independen terbebas dari multikolinieritas. 
Uji heterokedastisitas bertujuan untuk mengetahui apakah dalam sebuah model regresi terjadi ketidaksamaan varians dari residual suatu pengamatan ke pengamatan lain. Heterokedastisitas ditandai dengan adanya pola tertentu pada grafik scatterplot. Jika titik-titik yang ada membentuk suatu pola tertentu yang teratur, maka terjadi heterokedastisitas. Namun jika tidak ada pola yang jelas, yaitu serat titik-titik menyebar di atas dan di bawah angka 0 pada sumbu Y, maka tidak terjadi heterokedastisitas. Selain itu, heterokedastisitas dapat diketahui melalui uji Glesjer. Jika probabilitas masing-masing variabel independen > 0,05, maka tidak terjadi heterokedastisitas (Ghozali, 2006). Hasil uji menunjukkan bahwa pada scatterplot, titiktitik yang ada tidak membentuk sebuah pola namun menyebar, sehingga dapat disimpulkan bahwa dalam penelitian tidak terjadi heterokedastisitas. Selain itu melalui uji Glesjer nilai signifikansi masing-masing variabel $>0,05$, maka dapat disimpulkan tidak terjadi heterokedastisitas.

Hasil pengujian asumsi klasik menunjukkan bahwa model regresi yang dipakai telah memenuhi asumsi klasik sehingga dapat dilanjutkan dengan analisis regresi berganda. Model regresi berganda dalam penelitian ini adalah untuk menguji pengaruh perencanaan anggaran $\left(X_{1}\right)$, pelaksanaan anggaran $\left(X_{2}\right)$, pengadaan barang jasa $\left(X_{3}\right)$, komitmen manajemen $\left(X_{4}\right)$, lingkungan birokrasi $\left(\mathrm{X}_{5}\right)$, dan terhadap penyerapan angggaran $(\mathrm{Y})$.

Pengujian hipotesis dengan uji F (Fisher Test) dilakukan untuk menunjukkan apakah semua variabel independen yang digunakan dalam model regresi mempunyai pengaruh yang signifikan secara bersama-sama (simultan) terhadap variabel dependen. Berdasarkan tabel distribusi $F$, nilai $F_{\text {tabel }}=2,31$. Hasil uji $F$ didapatkan $F_{\text {hitung }}=55,419$, hal ini menunjukkan bahwa $F_{\text {hitung }}=55,419>F_{\text {tabel }}=2,31$ maka Ha diterima dan Ho ditolak. Dilihat dari nilai signifikansi menunjukkan bahwa nilai signifikansi adalah 0,000 $<0,05$ sehingga Ha diterima dan Ho ditolak. Hasil pengujian ini menunjukkan bahwa seluruh variabel independen yaitu perencanaan anggaran, pelaksanaan anggaran, pengadaan barang jasa, komitmen manajemen dan lingkungan birokrasi secara bersama-sama berpengaruh signifikan terhadap variabel dependen yaitu penyerapan anggaran.

Pengujian hipotesis dengan uji t dilakukan untuk mengetahui besarnya pengaruh masingmasing (parsial) variabel independen secara individual terhadap variabel dependen. Uji t juga dilakukan dengan membandingkan nilai $t_{\text {hitung }}$ dengan nilai $t_{\text {tabel }}$. Nilai $t_{\text {hitung }}$ diperoleh dari hasil perhitungan SPSS sedangkan $t_{\text {tabel }}$ diperoleh dari tabel distribusi t dicari pada $\alpha=5 \%: 2=2,5 \%$ (uji 2 sisi) dengan derajat kebebasan (df) n-k-1 atau 100-5-1 = 94. Dengan pengujian 2 sisi (signifikansi $=0,025$ ) hasil diperoleh untuk $t_{\text {tabel }}$ sebesar 1,98552 .

Pengaruh perencanaan anggaran terhadap penyerapan anggaran, nilai $t_{\text {hitung }}=2,338>t_{\text {tabel }}$ $=1,98552$ dan signifikansi sebesar 0,021 <0,05. Hal ini menunjukkan bahwa $\mathrm{Ha}_{1}$ diterima dan $\mathrm{Ho}_{1}$ ditolak, sehingga terbukti bahwa perencanaan anggaran berpengaruh positif dan signifikan terhadap penyerapan anggaran.

Pengaruh pelaksanaan anggaran terhadap penyerapan anggaran, $t_{\text {hitung }}=2,288>t_{\text {tabel }}=$ 1,98552 dan Signifikansi sebesar 0,024 $<0,05$. Hal ini menunjukkan bahwa $\mathrm{Ha}_{2}$ diterima dan $\mathrm{Ho}_{2}$ 
ditolak, sehingga terbukti bahwa pelaksanaan anggaran berpengaruh positif dan signifikan terhadap penyerapan anggaran.

Pengaruh pengadaan barang jasa terhadap penyerapan anggaran, nilai $t_{\text {hitung }}=2,048>t_{\text {tabel }}$ $=1,98552$ dan signifikansi sebesar 0,043 $<0,05$. Hal ini menunjukkan bahwa $\mathrm{Ha}_{3}$ diterima dan $\mathrm{Ho}_{3}$ ditolak, sehingga terbukti bahwa pengadaan barang jasa berpengaruh positif dan signifikan terhadap penyerapan anggaran.

Pengaruh komitmen manajemen terhadap penyerapan anggaran, $t_{\text {hitung }}=3,538>t_{\text {tabel }}=$ 1,98552 dan signifikan sebesar 0,001 $<0,05$. Hal ini menunjukkan bahwa $\mathrm{Ha}_{4}$ diterima dan $\mathrm{Ho}_{4}$ ditolak, sehingga terbukti bahwa komitmen manajemen berpengaruh positif dan signifikan terhadap penyerapan anggaran.

Pengaruh lingkungan birokrasi terhadap penyerapan anggaran, $t_{\text {hitung }}=2,454>t_{\text {tabel }}=$ 1,98552 dan signifikan sebesar 0,016 <0,05. Hal ini menunjukkan bahwa $\mathrm{Ha}_{4}$ diterima dan $\mathrm{Ho}_{4}$ ditolak, sehingga terbukti bahwa lingkungan birokrasi berpengaruh positif dan signifikan terhadap penyerapan anggaran.

Uji koefisien determinasi dalam regresi linear berganda, untuk regresi dengan lebih dari dua variabel bebas digunakan adjusted $R^{2}$ sebagai koefisien determinasi. Berdasarkan hasil uji, nilai adjusted $\mathrm{R}^{2}$ adalah 0,733 yang artinya penyerapan anggaran sebesar $73,3 \%$ dipengaruhi oleh perencanaan anggaran, pelaksanaan anggaran, pengadaan barang jasa, komitmen manajemen dan lingkungan birokrasi sedangkan sisanya $26,7 \%$ dipengaruhi oleh faktor lain di luar penelitian ini.

\section{Pengaruh perencanaan anggaran terhadap penyerapan anggaran}

Hasil pengujian hipotesis pertama menunjukkan bahwa variabel perencanaan anggaran $t_{\text {hitung }}=2,338>t_{\text {tabel }}=1,98552$ menunjukkan bahwa perencanaan anggaran berpengaruh positif dan signifikan terhadap penyerapan anggaran.

Sebagaimana hasil laporan Direktorat Jenderal Perimbangan Keuangan (2013) bahwa besar kecilnya tingkat penyerapan belanja daerah dalam mendanai pelayanan publik sangat dipengaruhi oleh proses perencanaan anggaran. Perencanaan yang buruk adalah hambatan yang signifikan mencegah penyerapan anggaran. Perencanaan anggaran memberi kontribusi besar terhadap penyerapan anggaran, sehingga semakin baik perencanaan anggaran akan semakin baik penyerapan anggaran.

Dalam Pemerintahan Daerah teori agency berlaku antara Pemerintah Provinsi/Kabupaten/Kota (agent) dan masyarakat (principal) melalui Dewan Perwakilan Rakyat Daerah (DPRD). Hubungan keagenan di Pemerintahan antara eksekutif dan legislatif, eksekutif (Pemerintah) adalah agent dan legislatif (DPRD) adalah principal. Sebelum penyusunan APBD dilakukan, terlebih dahulu dibuat kesepakatan antara eksekutif dan legislatif tentang arah dan kebijakan umum serta prioritas anggaran, yang akan menjadi pedoman dalam penyusunan APBD. Eksekutif membuat rancangan APBD yang kemudian diserahkan kepada legislatif untuk dipelajari dan dibahas bersama-sama sebelum ditetapkan sebagai Peraturan Daerah (Perda). Dalam perspektif keagenan hal ini merupakan bentuk kontrak yang menjadi alat bagi legislatif untuk mengawasi pelaksanaan anggaran oleh eksekutif.

Hasil penelitian ini mendukung penelitian Sukadi (2012) yang memberikan hasil bahwa perencanaan anggaran berpengaruh positif dan signifikan terhadap penyerapan anggaran. Demikian juga penelitian Malahayati (2015), memberikan hasil bahwa perencanaan anggaran berpengaruh positif terhadap penyerapan anggaran.

\section{Pengaruh pelaksanaan anggaran terhadap penyerapan anggaran}

Hasil pengujian hipotesis kedua menunjukkan bahwa variabel pelaksanaan anggaran, $t_{\text {hitung }}=2,288>t_{\text {tabel }}=1,98552$ sehingga pelaksanaan angggaran berpengaruh positif dan 
signifikan terhadap penyerapan anggaran. Nilai koefisien regresi pelaksanaan anggaran sebesar 0,148 menunjukkan jika pelaksanaan anggaran semakin baik, maka semakin baik pula penyerapan anggaran.

Dalam pengelolaan keuangan daerah, pelaksanaan anggaran baru dapat dilaksanakan setelah Rencana Kerja dan Anggaran (RKA) disahkan menjadi Dokumen Pelaksanaan Anggaran (DPA). Pelaksanaan anggaran merupakan suatu tindakan atau pelaksanaan dari sebuah rencana yang sudah disusun secara matang dan terperinci. Pelaksanaan anggaran akan tercapai dengan baik apabila perencanaan anggaran sudah dilaksanakan dengan baik (Miliasih, 2012).

Pelaksanaan anggaran merupakan tahapan pengelolaan keuangan yang harus dilaksanakan setelah proses perencanaan anggaran selesai. Pelaksanaan merupakan aktivitas atau usaha-usaha yang dilaksanakan untuk merealisasikan semua rencana dan kebijakan yang telah dirumuskan dan ditetapkan (BPKP, 2011). Proses pelaksanaan anggaran meliputi persoalan-persoalan yang terjadi dalam internal satuan kerja, serta proses mekanisme pembayaran (pencairan anggaran). Kedua hal tersebut mempengaruhi besar kecilnya penyerapan anggaran (Kuswoyo, 2011).

Pelaksanaan anggaran akan mempengaruhi penyerapan anggaran. Dalam perspektif teori agency, semakin baik pelaksanaan anggaran, maka penyerapan anggaran akan semakin baik. Hal ini akan mempengaruhi Satuan Kerja Perangkat Daerah (agent) menjalankan tupoksinya sejalan dengan tujuan organisasi dan seperti yang diinginkan masyarakat (principal).

Hasil penelitian ini mendukung penelitian Sukadi (2012) yang membuktikan bahwa pelaksanaan anggaran berpengaruh positif dan signifikan terhadap penyerapan anggaran. Begitu juga penelitian Malahayati (2015) memberikan hasil bahwa pelaksanaan anggaran mempunyai pengaruh positif terhadap penyerapan anggaran.

\section{Pengaruh Pengadaan Barang Jasa terhadap Penyerapan Anggaran}

Hasil pengujian hipotesis ketiga menunjukkan bahwa pada variabel pengadaan barang jasa, $t_{\text {hitung }}=2,048>t_{\text {tabel }}=1,98552$ sehingga pengadaan barang jasa berpengaruh positif dan signifikan terhadap penyerapan anggaran. Nilai koefisien regresi pengadaan barang jasa sebesar 0,087 menunjukkan jika proses pengadaan barang jasa baik maka penyerapan anggaran akan semakin baik.

Proses pengadaan barang jasa yang efektif dan efisien akan mempermudah proses penyerapan anggaran, dan berdampak pada mekanisme pembayaran (pencairan anggaran). Realisasi atas pembayaran kegiatan merupakan serapan anggaran (Herriyanto, 2012). Proporsi anggaran pengadaan barang jasa lebih dari 30-40 persen (Indonesia Procurement Watch, 2011) porsi yang besar tersebut dikarenakan pengadaan barang jasa merupakan kegiatan Pemerintah yang memiliki dampak luas terhadap perekonomian.

Kegagalan target penyerapan anggaran terkait pengadaan barang jasa yang dilakukan oleh Pemerintah (agent) akan berakibat hilangnya manfaat belanja karena dana yang telah dialokasikan ternyata tidak semuanya dapat dimanfaatkan, yang berarti adanya uang menganggur (idle money). Hal ini apabila berkaitan dengan pembangunan fisik (sarana dan prasarana) untuk fasilitas umum maka dampak keterlambatan ini akan mengakibatkan keterlambatan atas manfaat yang akan diterima dan dinikmati oleh masyarakat sebagai pemberi amanah (principal). Pada organisasi pemerintah, penyerapan anggaran dapat dijadikan salah satu indikator kinerja.

Hasil penelitian ini mendukung penelitian Kuswoyo (2011) yang membuktikan bahwa pengadaan barang jasa berpengaruh terhadap penyerapan anggaran. Begitu juga penelitian Sukadi (2012) memberikan hasil bahwa pengadaan barang jasa berpengaruh positif dan signifikan terhadap penyerapan anggaran. 


\section{Pengaruh Komitmen Manajemen terhadap Penyerapan Anggaran.}

Hasil pengujian hipotesis keempat menunjukkan bahwa pada variabel komitmen manajemen, $t_{\text {hitung }}=3,538>t_{\text {tabel }}=1,98552$ sehingga komitmen manajemen berpengaruh positif dan signifikan terhadap penyerapan anggaran. Nilai koefisien regresi komitmen manajemen sebesar 0,203 menunjukkan bahwa komitmen manajemen pada SKPD sangat tinggi untuk percepatan penyerapan anggaran. Dukungan Kepala SKPD sangat diperlukan untuk perbaikan penyerapan anggaran pada instansi yang dipimpinnya. Komitmen yang tinggi dari Kepala SKPD sangat mempengaruhi penyerapan anggaran.

Komitmen manajemen merupakan kegiatan melakukan dan mempertahankan perilaku yang membantu bawahan untuk mencapai suatu tujuan (Cooper,2006). Penekanan terhadap pelatihan, pemberdayaan dan penghargaan (Babakus et al, 2003), kontribusi berupa waktu yang diperlukan, sumber daya dan pendekatan positif terhadap proyek yang sedang dikerjakan (Marsh et al, 1998). Komitmen manajemen merupakan peran Kepala SKPD selaku pengguna anggaran dengan berbagai upaya untuk mencapai target penyerapan anggaran yang maksimal.

Penerima amanah dalam hal ini bawahan di SKPD (agent) berdasarkan pendelegasian dari pemberi amanah dalam hal ini Kepala SKPD (principal) dapat bekerja dengan baik karena diberikan kesempatan untuk mengadakan program kegiatan sesuai dengan kondisi Satuan Kerja sehingga diharapkan serapan anggaran dapat berjalan sesuai dengan yang diharapkan.

Hasil penelitian ini mendukung penelitian yang dilakukan Juliani (2014) yang memberikan hasil bahwa komitmen manajemen berpengaruh positif terhadap penyerapan anggaran.

\section{Pengaruh Lingkungan Birokrasi terhadap Penyerapan Anggaran}

Hasil pengujian hipotesis kelima menunjukkan bahwa variabel lingkungan birokrasi, $t_{\text {hitung }}$ $=2,454>t_{\text {tabel }}=1,98552$ sehingga lingkungan birokrasi berpengaruh positif dan signifikan terhadap penyerapan anggaran. Nilai koefisien regresi lingkungan birokrasi sebesar 0,102 menunjukkan bahwa kondisi yang mendukung di SKPD sangat mempengaruhi percepatan penyerapan anggaran.

Birokrasi merupakan alat atau mekanisme yang dibuat untuk kesuksesan dan efisiensi suatu pelaksanaan kegiatan untuk mencapai tujuan atau sasaran tertentu (Eisenstadt, 1959). Kondisi atau keadaan yang ada pada pemerintah daerah akan sangat mempengaruhi berjalan lancar atau tidak kegiatan mereka.

Lingkungan birokrasi yang baik akan membuat pelaksanaan kegiatan operasional menjadi lancar. Namun jika lingkungan birokrasi tidak mendukung kegiatan organisasi maka akan menghambat kinerja organisasi (Eisenstadt, 1959). Oleh karena itu, lingkungan birokrasi akan mempengaruhi penyerapan anggaran.

Semakin baik koordinasi dalam implementasinya antara penerima amanah (agent) dan pemberi amanah (principal) akan semakin memudahkan pemegang amanah (agent) dalam melaksanakan program dan kegiatan yang ada di Satuan Kerja, sehingga diharapkan serapan anggaran dapat lebih cepat dilakukan.

Hasil penelitian ini mendukung penelitian Juliani (2014) yang memberikan hasil bahwa lingkungan birokrasi berpengaruh positif terhadap penyerapan anggaran. Lingkungan birokrasi mempengaruhi penyerapan anggaran karena adanya dukungan dan kekondusifan kondisi dan keadaan di SKPD dapat mendukung penyerapan anggaran menjadi lebih baik.

\section{Kesimpulan dan Saran}

Hasil Penelitian menunjukkan bahwa baik secara simultan maupun parsial perencanaan anggaran, pelaksanaan anggaran, pengadaan barang jasa, komitmen manajemen dan lingkungan 
birokrasi berpengaruh terhadap penyerapan anggaran pendapatan dan belanja daerah (APBD) Pemerintah Kabupaten Kepulauan Talaud.

Saran yang dapat diberikan dalam penelitian ini agar Pemerintah Kabupaten Kepulauan Talaud, dalam upaya untuk meningkatkan penyerapan anggaran diharapkan dapat memberikan perhatian yang serius terhadap permasalahan penyerapan anggaran, dengan cara terus memperbaiki proses perencanaan anggaran mulai dari penyusunan RKA sampai dengan Penetapan APBD. Mempercepat proses pelaksanaan anggaran dengan cara menerbitkan SK Pejabat Perbendaharaan tepat waktu, tidak menunda pekerjaan, proses penyelesaian administrasi tepat waktu, dalam pelaksanaan anggaran mengacu pada DPA dan Anggaran Kas yang telah disahkan. Melakukan proses pengadaan barang jasa sesuai dengan peraturan perundang-undangan yang berlaku. Meningkatkan komitmen manajemen dengan cara mendukung pelatihan/bimbingan teknis bagi para pegawai, menciptakan lingkungan birokrasi yang baik dengan cara menjalin koordinasi yang baik antar pegawai.

\section{Daftar Pustaka}

Babakus, E., U. Yavas, O, M. Karatepe, and T. Avci, 2003. The Effect of Management Commitment to Service Quality on Employees' Affective and Performance Outcomes. Journal of the Academy of Marketing Science, 272-286.

Bastian, Indra. 2006. Akuntansi Sektor Publik: Suatu Pengantar. Penerbit Erlangga. Jakarta BPKP. 2011. Menyoal Penyerapan Anggaran. Yogyakarta Review.

Cooper, M. D. 2006. Exploratory Analyses of the Effects of Managerial Support and Feedback Consequences on Behavioral Safety Maintenance. Journal of Organizational Behavior Management, 1-41.

Dharmanegara, Ida Bagus Agung. 2010. Penganggaran Perusahaan. Teori dan Aplikasi. Yogyakarta: Graha Ilmu.

Direktorat Jenderal Perimbangan Keuangan. 2013. Perencanaan dan Penganggaran Daerah Kursus Keuangan Daerah. Jakarta: Kementerian Keuangan Republik Indonesia.

Eisenhardt. M. Kathleen. 1989. Agency Theory : An Assessment and Review, Academy of Management Review.

Eisenstadt, S. N. 1959. Bureaucracy, Bureaucratization, and Debureaucratization. Administrative Science Quarterly, 302-320.

Ghozali, Imam. 2005. Aplikasi Analisis Multivariate Dengan Program SPSS Edisi Keempat. Semarang : Badan Penerbit Universitas Diponegoro.

2006. Aplikasi Analisis Multivariate dengan Program SPSS. Semarang: Badan Penerbit-UNDIP.

Halim, A. dan S. Kusufi. 2012. Akuntansi Sektor Publik dari Anggaran hingga Laporan Keuangan, dari Pemerintah hingga Tempat Ibadah. Jakarta: Salemba Empat.

Herriyanto. Hendris. 2012. Faktor-faktor Yang Mempengaruhi Keterlambatan Penyerapan Anggaran Belanja Pada Satuan Kerja Kementerian/Lembaga di Wilayah Jakarta. Tesis. Jakarta: Universitas Indonesia

Indonesia Procuremnet Watch (IPW). 2011. Laporan Survei Jejak Suap Dalam Pengadaan Barang/Jasa Pemerintah.

Juliani. Dian. 2014. Pengaruh Faktor-faktor Konstektual Terhadap Persepsian Penyerapan Anggaran Terkait Pengadaan Barang/Jasa. Tesis-Jurnal. Yogyakarta: Universitas Gajah Mada.

Kuswoyo. 2011. Analisis Faktor-faktor Yang Menyebabkan Terkonsentrasinya Penyerapan Anggaran Belanja diakhir Tahun Anggaran (Studi Pada Satuan Kerja di Wilayah KPPN Kediri). Tesis-Abstrak. Yogyakarta : Universitas Gajah Mada. 
Malahayati. Cut. 2015. Pengaruh Kapasitas Sumber Daya Manusia, Perencanaan Anggaran dan Pelaksanaan Anggaran Terhadap Serapan Anggaran Satuan Kerja Perangkat Daerah (SKPD) Pada Pemerintah Kota Banda Aceh. Tesis-Jurnal. Aceh: Universitas Syiah Kuala.

Marsh, T. W. etal. 1998. The Role of Management Commitment in Determining the Success of a Behavioural Safety Intervention. Journal of the Institution of Occupational Safety \& Health, 2 (2), 45-56.

Miliasih. 2012. Analisis Keterlambatan Penyerapan Anggaran Belanja Satuan Kerja Kementerian Negara/Lembaga T.A. 2010 di Wilayah Pembayaran KPPN Pekanbaru. Tesis. Jakarta : Universitas Indonesia.

Priyanto, Duwi. 2013. Analisis Korelasi, Regresi dan Multivariate dengan SPSS. Penerbit Gava Media Yogyakarta.

Republik Indonesia. Undang-undang Nomor 17 Tahun 2003 tentang Keuangan Negara. Jakarta. . Undang-Undang Nomor 9 Tahun 2015 tentang Pemerintah Daerah. Jakarta. . Peraturan Presiden Nomor 54 Tahun 2010 tentang Pengadaan Barang Jasa Pemerintah. Jakarta.

. Peraturan Pemerintah Nomor 70 Tahun 2012 tentang Perubahan Kedua Peraturan Presiden Nomor 54 Tahun 2010 tentang Pengadaan Barang Jasa Pemerintah. Jakarta . Peraturan Menteri Keuangan Nomor 249/PMK.02 Tahun 2011 tentang Pengukuran dan Evaluasi Kinerja atas Pelaksanaan Rencana Kerja dan Anggaran Kementerian Negara/Lembaga. Jakarta

Rodgers, R., J. E. Hunter, and D.L. Rogers. 1993. Influences of Top Management Program Success. Journal of Applied Psychology. 151-155.

Sugiyono. 2012. Metode Penelitian Kuantitatif, Kualitatif dan $R \& D$. Bandung: Penerbit Alfabeta.

Sukadi. 2012. Analisis Faktor-Faktor Yang Mempengaruhi Penumpukan Penyerapan Anggaran Belanja Pada Akhir Tahun Anggaran. Tesis-Abstrak. Yogyakarta: Universitas Gajah Mada. 